\title{
A review of current and possible future human-water dynamics in Myanmar's river basins
}

\author{
Linda Taft and Mariele Evers \\ Department of Geography, University of Bonn, Meckenheimer Allee 166, 53315 Bonn, Germany \\ Correspondence to: Linda Taft (ltaft@uni-bonn.de)
}

Received: 8 December 2015 - Published in Hydrol. Earth Syst. Sci. Discuss.: 15 January 2016

Revised: 8 November 2016 - Accepted: 23 November 2016 - Published: 15 December 2016

\begin{abstract}
Rivers provide a large number of ecosystem services and riparian people depend directly and indirectly on water availability and quality and quantity of the river waters. The country's economy and the people's well-being and income, particularly in agriculturally dominated countries, are strongly determined by the availability of sufficient water. This is particularly true for the country of Myanmar in South-east Asia, where more than $65 \%$ of the population live in rural areas, working in the agricultural sector. Only a few studies exist on river basins in Myanmar at all and detailed knowledge providing the basis for human-water research is very limited. A deeper understanding of human-water system dynamics in the country is required because Myanmar's society, economy, ecosystems and water resources are facing major challenges due to political and economic reforms and massive and rapid investments from neighbouring countries. However, not only policy and economy modify the need for water. Climate variability and change are other essential drivers within human-water systems. Myanmar's climate is influenced by the Indian Monsoon circulation which is subject to interannual and also regional variability. Particularly the central dry zone and the Ayeyarwady delta are prone to extreme events such as serious drought periods and extreme floods. On the one hand, the farmers depend on the natural fertiliser brought by regular river inundations and high groundwater levels for irrigation; on the other hand, they suffer from these water-related extreme events. It is expected that theses climatic extreme events will likely increase in frequency and magnitude in the future as a result of global climate change. Different national and international interests in the abundant water resources may provide opportunities and risks at the same time for Myanmar. Several dam projects along the main courses of the rivers are currently in the plan-
\end{abstract}

ning phase. Dams will most likely modify the river flows, the sediment loads and also the still rich biodiversity in the river basins, to an unknown extent. Probably, these natural and anthropogenically induced developments will also impact a special type of farming; we call it alluvial farming in the river floodplains and on sandbars in the Ayeyarwady River basin in Myanmar, which is called Kaing and Kyun, respectively.

Relevant aspects for future development of Myanmar's river basins combine environment-water-related factors, climate, economic and social development, water management and land use changes. Research on these interplays needs to capture the spatial and temporal dynamics of these drivers. However, it is only possible to gain a full understanding of all these complex interrelationships if multi-scale spatiotemporal information is analysed in an inter- and trans-disciplinary approach. This paper gives a structured overview of the current scientific knowledge available and reveals the relevance of this information with regard to human-environment and particularly to human-water interactions in Myanmar's river basins. By applying the eDPSIR framework, it identifies key indicators in the Myanmar human-water system, which has been shown to be exemplary by giving an example of use related to alluvial farming in the central dry zone.

\section{Introduction}

Rivers provide a large number of ecosystem services, e.g. water supplies, food source, and biodiversity conservation or drought mitigation, and river basins are home to almost 1 billion people worldwide (Postel and Richter, 2003; Allen et al., 2010; Di Baldassarre et al., 2013). Riparian peo- 
ple depend directly and indirectly on water availability and quality and quantity of the river waters, which are, in turn, influenced by precipitation, evaporation, glacial meltwater in the river source areas, and increasing human impact. For example, pollution, increasing water use for irrigation and dam building alter the quality and availability of river waters. Additionally, anthropogenic climate change will possibly impact flow regimes and the water demand. Rivers worldwide are under pressure due to multiple uses which often have severe impacts on ecosystems or water quality and flow. Vörösmarty et al. (2010) stated that $65 \%$ of global river discharge, and the aquatic habitats supported by this water, are under moderate to high threat of biodiversity loss.

The country's economy and the people's well-being and income, particularly in agriculturally dominated countries, strongly depend on the availability of sufficient water. This is particularly true for the country of Myanmar in South-east Asia, where more than $65 \%$ of the population live in rural areas, working in the agricultural sector (FAO, 2014). The Ayeyarwady River (also referred to as the Irrawaddy River) catchment covers $413700 \mathrm{~km}^{2}$, which represents about $61 \%$ of the country. Thus it is the most important river system in Myanmar. The mighty Ayeyarwady River is called the lifeline of the nation because it serves for transportation, domestic and industrial water supply, irrigation, a high biodiversity and fishing. This river is highly important for Myanmar but is the least known among the large Asian rivers (Furuichi et al., 2009). Since the end of Myanmar's political and economic isolation in 2011, the country's abundant water resources have faced major changes. It is assumed that the current and future progressive socio-economic development of the country have and will have a significant impact on the water resources (Kattelus et al., 2014). However, not only political, economic and demographic changes have and will have major effects on the natural water resources. The headwaters of the Ayeyarwady River are fed by glacier melt in the Himalayan Mountains and the river discharge is likely to change due to climate change impacts. Myanmar's climate is directly influenced by the Indian summer monsoon (ISM; Sen Roy and Kaur, 2000; Sein et al., 2015), which is the second basic source of Myanmar's rivers. It is currently still not predictable whether the complex Asian monsoon circulation will strengthen, weaken or become more variable as a result of global warming (Turner and Annamalai, 2012; IPCC, 2014). Already now there seems to be a trend to a delay and an earlier ending of the monsoon rains of 2 weeks in Myanmar respectively (Irrawaddy, 2015). On the one hand, the Burmese riparian people depend on frequent river floods for agriculture, particularly rice production in the river delta regions. On the other hand, extreme flood events can cause destructive effects. Just recently, the western part of the country was affected by very heavy monsoon rains in August 2015. Thousands of people had to be evacuated and more than 100 people died (Burki, 2015). The occurrence of extreme weather events like floods, cyclones and severe droughts has shown an increasing trend over the last 6 decades in Myanmar, most likely as a result of climate change (GCCA, 2012).

Only a few studies exist on river basins in Myanmar at all and detailed knowledge is very limited (e.g. Varis et al., 2012; Salmivaara et al., 2013). However, more research on human-water dynamics in the country is strongly required because Myanmar's society, economy, ecosystems and water resources are facing major challenges due to political and economic reforms, massive and rapid investments from neighbouring countries (particularly from China and Thailand; Webb et al., 2012) and climate change impacts. There is a large amount of grey literature such as reports and workshop presentations from NGOs, political institutions and Burmese and international organisations, dealing with human and climate impacts and the water resources in Myanmar. However, systematically compiled English scientific publications on this topic have not been published yet. Hence, English grey literature and peer-review publications on current and likely future impacts from human activities and climate change on Myanmar's river basins have been reviewed by the authors in order to gain an overview of the key drivers in these human-water dynamics.

Following a socio-ecological understanding we hypothesise that all components (e.g. stakeholders, water resources, climate, aquatic fauna) within the Burmese river basins interact and that the degree of interactions between driving forces (e.g. foreign investments, water demand, water management measures, regional climate change) and feedbacks permanently change. If, for example, the demand for domestic water increases due to a dry spell, the riparian people will increasingly extract river water as well as groundwater. This higher water extraction in turn will probably impact the aquatic ecosystem, which has potential negative effects on the fisheries and therefore also on the economic income of the people.

The major aim of this review was to compile the naturally given physical conditions and the socio-economical features in terms of land and water use in order to make this information internationally accessible in a scientific status quo review paper. The first part of the paper provides general information on physical features with focus on the river basins, followed by socio-economical features. Section 4 concentrates on possible future impacts with focus on climate change. Based on the reviewed literature we attempt to structure the information on human-water dynamics by means of the eDPSIR (enhanced driving force-pressure-state-impactresponse) framework by Niemeijer and de Groot (2008a, b). We applied this framework by using a concrete example in order to identify important key nodes within a causal network of various driving forces, feedback mechanisms, impacts and responses on the societal and physical-environmental sides. Open research gaps concerning human-water dynamics in Myanmar and recommendations for research approaches have been identified and elaborated at the end. 


\section{Physical features}

The Republic of the Union of Myanmar $\left(9^{\circ} 55^{\prime}-28^{\circ} 15^{\prime} \mathrm{N}\right.$, $\left.92^{\circ} 10^{\prime}-101^{\circ} 11^{\prime} \mathrm{E}\right)$ is a South-east Asian country located between Bangladesh and India to the west, China to the north and north-east, Laos and Thailand to the east and the Bay of Bengal and the Andaman Sea to the south-west and south (Fig. 1). The maximum north-south extent is about $2500 \mathrm{~km}$ and the maximum west-east extent is ca. $900 \mathrm{~km}$. At $676578 \mathrm{~km}^{2}$, Myanmar (Department of Population, 2015) is the second largest country in South-east Asia after Indonesia.

\subsection{Geology and geomorphology}

The country slopes downward in elevation from north to south and the central lowlands are surrounded by steep mountain ranges (Fig. 1). Three mountain ranges trending from north to south, namely the Rakhine Yoma (the term Yoma means mountain range), the Bago Yoma and the Shan Plateau (from west to east), divide the country (Fig. 1). The Rakhine and Bago mountain ranges have been thrust up through the collision of the Indian-Australian and Eurasian plates for the past 50 million years (Bender, 1983). The Shan Plateau was already formed during the Mesozoic era and it has an average elevation of about $900 \mathrm{~m}$ a.s.l. (Hadden, 2008). The topography can be divided into five sub-regions: (1) the northern mountains including the highest point of Myanmar - Mount Hkakabo Razi (5881 ma.s.1.); (2) the western Rakhine ranges; (3) the eastern Shan Plateau; (4) the central basins and lowlands and (5) the coastal plains including the wide Ayeyarwady delta. Mount Hkakabo Razi is part of a geological complex where the Indian-Australian plate has been colliding with the southern edge of the Eurasian plate since the Eocene (Hadden, 2008). This northern mountain region is the source area of several of Asian's great rivers, including the Irrawaddy. The central basin lies between the western Rakhine ranges and the eastern Shan Plateau in the rain shadow of the monsoon precipitations. The Ayeyarwady, Chindwin and Sittaung rivers cover soft sandstones, shales and clays with their fertile alluvial deposits in the central basin (Bender, 1983). The coastline has a length of about $3000 \mathrm{~km}$ and there are numerous islands of varying sizes $(\mathrm{Oo}, 2002)$.

\subsection{Hydrogeography}

Major rivers are the Ayeyarwady, the Salween, the Chindwin and the Sittaung. All these rivers are understudied river basins (Salmivaara et al., 2013), despite their great importance for the Burmese people's lives and the nation's economy. The north-south trending courses of most of the Burmese rivers are geologically predetermined following the mountain ranges Rakhine and Bago and the Shan Plateau.

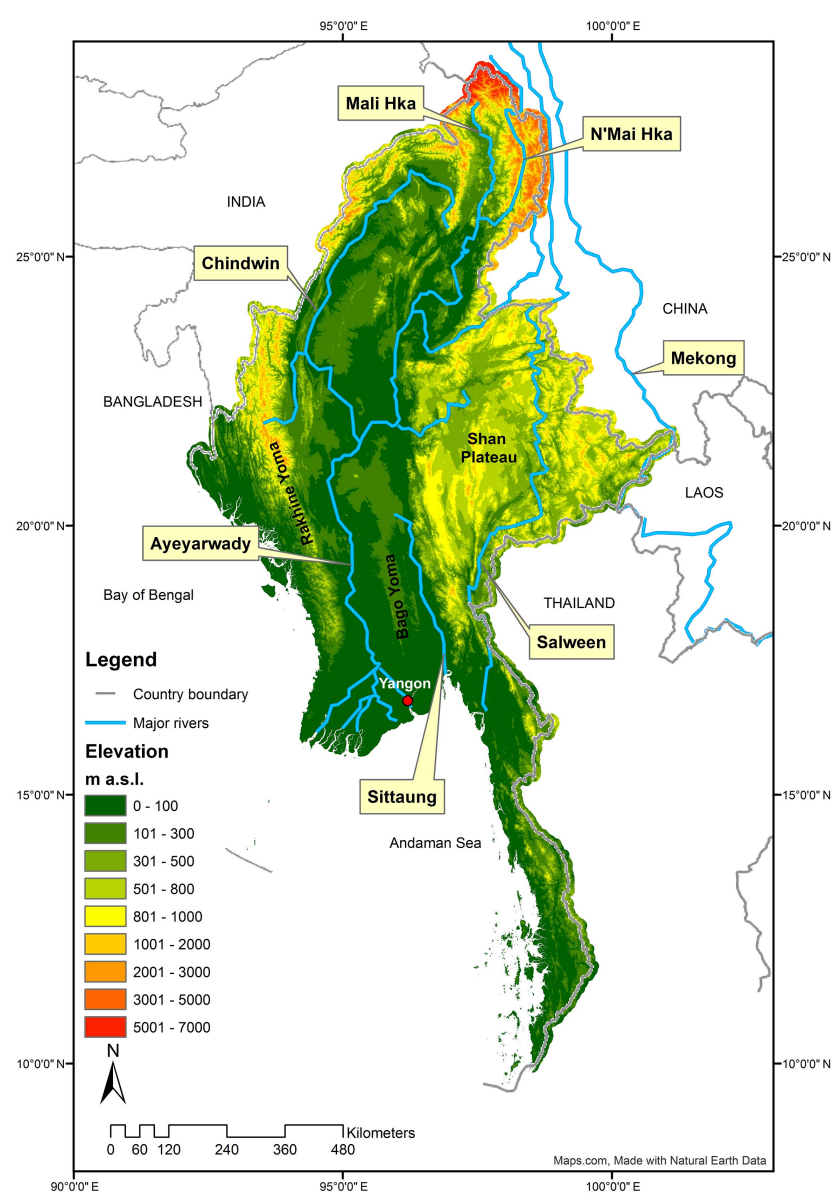

Figure 1. Physical overview map of Myanmar including state border lines, major rivers and mountain ranges.

For about $230 \mathrm{~km}$, the transnational Mekong River forms the border between Myanmar and Laos (Fig. 1).

The Ayeyarwady River is Myanmar's most important commercial waterway (Salween Watch and SEARIN, 2004). It is about $2170 \mathrm{~km}$ long and originates at the confluence of the Mali Hka and N'Mai Hka rivers in northern Kachin state (Fig. 1). The headwaters of both rivers originate in the eastern syntaxis of the Himalayas and the Tibetan Plateau in Yunnan Province, China. The river basin of the Ayeyarwady covers around $413700 \mathrm{~km}^{2}$, of which $95 \%$ is located in Myanmar (Salween Watch and SEARIN, 2004; Bird et al., 2008). The broad fertile lowland floodplain is extensively used for agriculture. The river is fed by glacial meltwater in the source areas of the Mali Hka and N'Mai Hka rivers as well as by precipitation. Based on data collection between 1969 and 1996 by Furuichi et al. (2009), the average annual discharge is $379 \pm 47 \times 10^{9} \mathrm{~m}^{3} \mathrm{yr}^{-1}$, and around $70 \%$ of it occurs between July and October (Robinson et al., 2007). The Ayeyarwady has the fifth highest sediment load of any major river worldwide (Furuichi et al., 2009; World Bank, 2014). Furuichi et al. (2009) estimated the suspended sediment load 
to be $325 \pm 57 \times 10^{6} \mathrm{t}$ annually. However, the river is navigable year-round for approximately $1500 \mathrm{~km}$ from Yangon, but sandbanks and shallow sections make it often difficult to navigate during the dry season (Lwin, 2014). The basin's ecosystem is very rich and dynamic and the river is home to the endangered Irrawaddy dolphin (Smith et al., 2009; Aung et al., 2013).

With a total length of about $2800 \mathrm{~km}$, the transboundary (China, Thailand, Myanmar) Salween River is one of the longest rivers in South-east Asia. However, it is navigable for only $150 \mathrm{~km}$ from its delta due to its rapids and deep gorges (Salween Watch and SEARIN, 2004). Annual runoff is approximately $210 \mathrm{~km}^{3}$ (Robinson et al., 2007). The source of the river is located on the Tibetan Plateau and subsequently the water flows through Yunnan Province in China to the eastern part of Myanmar where the Salween drains the Shan Plateau. For approximately $120 \mathrm{~km}$, the river forms the border between Myanmar and Thailand until it flows to the Andaman Sea in the Gulf of Martaban (Salween Watch and SEARIN, 2004; Fig. 1). The river basin covers $320000 \mathrm{~km}^{2}$ and has one of the most diverse ethnic concentrations worldwide (Salween Watch and SEARIN, 2014). Furthermore, the basin is very rich in natural resources, including surface and groundwater, forest, wildlife, fisheries and minerals (FAO, 2011).

The Chindwin River has existed since at least the Eocene and is the largest tributary of the Ayeyarwady (Hedley et al., 2010). It has a length of about $1200 \mathrm{~km}$ (Salween Watch and SEARIN, 2014). The Chindwin rises in the Kumon Range in northern Myanmar and reaches the Ayeyarwady near Mandalay in the central dry zone. For about $600 \mathrm{~km}$ the river is navigable from its confluence with the Ayeyarwady River (Ministry of Forestry of the Union of Myanmar, 2005). Most of its course has not been studied yet due to the difficulty of access (Salween Watch and SEARIN, 2004).

The Sittaung River originates at the southern edge of the Shan Plateau and drains after $420 \mathrm{~km}$ into the Gulf of Martaban of the Andaman Sea (Salween Watch and SEARIN, 2004). Year-round, the Sittaung River is navigable only for 40 and $90 \mathrm{~km}$ during the rainy season. It is mainly used for floating teak wood for export to the south. At its lower course, the river is linked by a canal to the Bago River, located in Yangon (Fig. 1).

The Ayeyarwady delta is one of the major tropical deltas worldwide (Hedley et al., 2010). Its current extensive wedgeshape originated around 7000-8000 years ago and it comprises $>20500 \mathrm{~km}^{2}$ of flat, low-lying fertile delta plain with five major tributaries (Hedley et al., 2010; Woodroffe, 2000). The delta area continues upriver at sea level for more than $200 \mathrm{~km}$ (Webster, 2008). The delta plain hosts a fragile and complex ecosystem of mangrove swamps and tidal estuaries (Salween Watch and SEARIN, 2004). Mangrove forests play an important role in delta evolutions because they act as sediment traps, primary colonisers and bio-shields against impacts of cyclones and tsunamis. However, the ecological sta- tus of the Ayeyarwady mangroves is continuously declining due to increasing rice production, land use changes and population growth (Ministry of Forestry of the Union of Myanmar, 2005; Webb et al., 2014). The Ayeyarwady delta is under intensive land use and the population density is the second highest $\left(177 \mathrm{~km}^{2}\right)$ in the entire country, after Yangon $\left(716 \mathrm{~km}^{2}\right.$ ) (Salmivaara et al., 2013; Department of Population, 2015). Saline water penetrates up to $100 \mathrm{~km}$ upstream due to tidal influences (Aung, 2003 in Hedley et al., 2010). Drainage, flood protection and salt intrusion are major concerns in the Ayeyarwady delta (FAO, 2015). The Salween River has rather a river mouth than a clearly developed delta and is less populated. However, the Salween River mouth area is facing similar environmental pressures, only on a smaller scale (Salmivaara et al., 2013).

\subsection{Soil types}

Due to the wide range of climatic and geologic conditions, soil types in Myanmar vary accordingly. Fertile alluvial soils are predominantly located in the river basins of the Ayeyarwady, lower Salween and Chindwin rivers (MOAI, 2001). These soils are of high importance for farming (see Sect. 3.1). Red-brown and yellow-brown forest soils (cambisols following the FAO soil classification or inceptisols following the USDA soil classification) are found in the hilly areas of the mountain ranges and their forelands. These soils are suitable for forest plantation (Ministry of Forestry of the Union of Myanmar, 2005). The central part of the country is covered with red-brown and dark compact savanna soils which are susceptible to soil erosion and dryland salinity. The humus content of red earths is relatively high $(<8 \%)$ and thus this soil type is very suitable for diversified agriculture which can be found from the eastern Mandalay Division to large parts of the Shan Plateau (Ministry of Forestry of the Union of Myanmar, 2005).

\subsection{Climate}

Few regional studies exist on modern climate conditions in Myanmar. In general, large parts of the country have a tropical monsoon climate. Due to the diverse orography of the country ranging from low-lying delta regions to high mountainous terrain, the climate can be divided into the following five sub-types according to the Köppen-Geiger climate classification (Peel et al., 2007): (1) tropical, monsoon climate (Am) along the coastlines and the western part; (2) tropical, savannah climate (Aw) in the central and eastern parts; (3) temperate, dry winter, hot summer climate (Cwa) in the north-eastern mountainous area; (4) temperate, dry winter, warm summer climate $(\mathrm{Cwb})$ in the northern part, a small area subsequent to the Cwa climate region and (5) temperate, without a dry season, warm summer $(\mathrm{Cfb})$ in the most north-easterly high mountain area. 

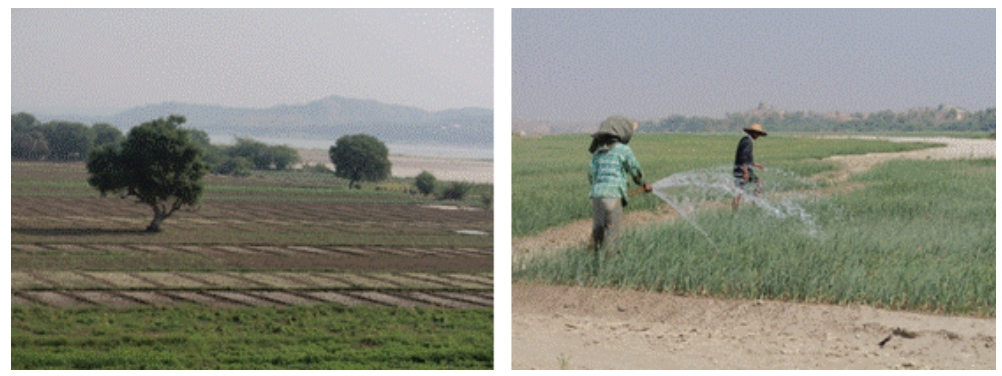

Figure 2. Left panel: example of Kaing farming (farmlands which appear in the flood plain in the Ayeyarwady River) in Magway district (Chauk). Right panel: example of Kyun farming (farmlands which appear on sandbars in the Ayeyarwady River) in Pakkoku township. Pictures taken by M. Evers.

Palaeoclimate research in Myanmar is very scarce, although findings about past monsoon variabilities in this region would definitely contribute to a deeper understanding of this atmospheric circulation. There are teak tree ring chronologies covering the last 3 centuries in Myanmar (D’Arrigo et al., 2011; D'Arrigo and Ummenhofer, 2015). Following these studies, the tree-ring records show monsoon rainfall variabilities consistent with results from surrounding countries, indicating that Myanmar is influenced by the same atmospheric circulation system. Sen Roy and Kaur (2000) noted that even though India and Myanmar are geographical neighbours and are influenced by the same monsoon system, Myanmar's rainfall seems to have no significant relationship with the rainfall of northern India. This pattern might be due to the fact that the Rakhine Mountains (<3800 m a.s.l.) located in the western part of Myanmar (Fig. 1) redirect the wind flows. In contrast, D'Arrigo et al. (2011) detected a positive correlation of monsoon variability in Myanmar with the monsoon larger-scale indices over northeastern India based on teak tree-ring chronology for the last 3 centuries. These contrary findings highlight the urgent need for more climate research in Myanmar.

\section{Precipitation}

Myanmar's climate is largely influenced by the Indian summer monsoon as well as by convective rainfall from the Bay of Bengal (Sen Roy and Kaur, 2000; D'Arrigo et al., 2011; Htway and Matsumoto, 2011; Sein et al., 2015). The patterns of rainfall indicate considerable complexity, particularly in summer, when Indian and East Asian monsoon circulations interact (D'Arrigo et al., 2011). Previously, Maung (1945) studied the forecasting of coastal monsoon rainfalls in Myanmar; however, his study does not include a detailed description of the general climatology. Sen Roy and Kaur (2000) gave an overview of the climatology of monsoon rains of Myanmar using 33 years (1947-1979) of station-level monthly data. After this study, about $75 \%$ of the country's annual average rainfall is from June to September (Sen Roy and Kaur, 2000). Sein et al. (2015) concluded that the summer monsoon accounts for almost $90 \%$ of Myanmar's observed rainfall. The monsoon rains reach the southern part of Myanmar by around the third week of May and cover the entire country by the beginning of June (Sen Roy and Kaur, 2000). Results of a study by Sen Roy and Sen Roy (2011) showed the existence of five homogenous precipitation regions, namely, northern, western, central, eastern and southern Myanmar. There the amount of annual precipitation varies between 500 and $1000 \mathrm{~mm}$ in the central dry zone (Johnston et al., 2013; FAO, 2015) and by up to $4000-6000 \mathrm{~mm}$ at the western coast (MOAI, 2001; FAO, 2015). The central dry zone lies in the rain shadow of the Rakhine Mountains located along the western coastline (Fig. 2). This area receives only $3.2 \%$ of the country's total rainfall (Ministry of Forestry of the Union of Myanmar, 2005). Easterly winds and local depressions in the Gulf of Thailand can cause post-monsoon rains from mid-October to the end of November (MOAI, 2001; Sein et al., 2015). A correlation between El Niño-Southern Oscillation (ENSO) and the variability of Asian monsoon intensity has been discussed extensively during the last decades (e.g. Kumar et al., 1999; Torrence and Webster, 1999; Xavier et al., 2007; Li and Ting, 2015). All these studies conclude a significant correlation between both atmospheric circulations. Current research from Sein et al. (2015) indicated that El Niño events can result in drought periods in Myanmar, while La Niña events can result in more extreme floods due to intensified monsoon rains.

The average temperature varies from 21 to $34^{\circ} \mathrm{C}$ in the hot season and from 11 to $23^{\circ} \mathrm{C}$ in the cool season, depending on location and elevation. The mean relative humidity ranges between 58 and $79 \%$ (Ministry of Forestry of the Union of Myanmar, 2005). Average diurnal temperatures show little variation across the country, ranging from 26 to $28^{\circ} \mathrm{C}$ between Sittwe in the western region, Yangon near the southern coast and Mandalay in the central dry zone. During the rainy season, the diurnal temperatures range between 25 and $33^{\circ} \mathrm{C}$ and from 10 to $25^{\circ} \mathrm{C}$ during the cold season. Between midApril and mid-May, the maximum temperatures rise continuously in the whole country (Htway and Matsumoto, 2011). The maximum diurnal temperatures in the central dry zone can reach $>43^{\circ} \mathrm{C}$ in the hot season prior to the monsoon 
season (Aung, 2002). In this area, the mean monthly potential evapotranspiration exceeds the mean monthly rainfall.

\subsection{Hydro-meteorological extreme events and climate variability}

Myanmar is considerably prone to risks from weather extremes and climate variability. According to the Germanwatch Global Climate Risk Index, Myanmar is one of the countries worldwide affected most by extreme weather events between 1993 and 2012 (Kreft and Eckstein, 2014). The coast, the river delta zones and the central dry zone are the most vulnerable areas for weather extreme events like cyclones, river floods, storm surges and drought periods. Climate variability is a major concern for the country since the majority of Myanmar's economy and people's income and well-being are dependent on the right timing and amount of monsoon rains. Myanmar's farmers strongly depend on monsoon precipitation since they use the water for irrigating rainfed rice paddies and storing the rain water for the dry season. However, extreme amounts of monsoon rains have the potential to destroy their livelihoods. Extreme and long-lasting dry periods or extremely low amounts of monsoon rains cause water scarcity and threaten the food security of the country.

\subsubsection{Floods}

Floods can represent a basic asset for people's well-being, income and cultures but also a drawback for societal and economic development. Myanmar is regularly affected by severe floods comprising river floods, flash floods, pluvial floods and coastal floods. Catastrophic flash floods associated with high rainfall occurred in the central dry zone, e.g. in the year 2011 (Rao et al., 2013). Just recently, the western part of the country was affected by very heavy monsoon rains in August 2015. Particularly, the Ayeyarwady delta zone and the central dry zone are extremely vulnerable to impacts from floods due to associated crop loss and the relatively dense population. In hilly and mountainous rural areas, heavy rainfalls often trigger disastrous landslides, with severe consequences for the Burmese people, who normally live in small wooden huts. The flood risk of Myanmar is assessed as very high due to high vulnerability and low capacity to cope with floods. For the future, the frequency of 100-year floods in Myanmar is likely to increase (Hirabayashi et al., 2013).

\subsubsection{Droughts}

Increasing pressure on water resources and water scarcity is becoming a worldwide problem in most arid and semi-arid regions (Kahil et al., 2015). Particularly in the central dry zone of Myanmar, rainfall is associated with high heterogeneity across space and time (McCartney et al., 2013). Precipitation amounts in the dry zone are generally less compared to other regions in Myanmar (see Sect. 2.2.1). In the context presented here, a drought is considered as a tempo- rary extreme dry period characterised by below-normal precipitation over a period of months or even years (Dai, 2011). Severe drought periods in e.g. the years 1997-1998, 2010 and 2014 led to crop failures and water shortage in the central dry zone where more than 14 million people predominantly practice agriculture. Most of the wells dried up due to the sinking of groundwater levels (DMH, 2015). Due to a strong El Niño impact since 2015, the country, and particularly the dry zone and the Ayeyarwady delta, have been severely affected by drier than average conditions associated with risks such as fire hazards, drought, disease and food insecurity (FAO, 2016). The sources of income are affected by drought periods as well as the quality and availability of domestic and drinking water, which can have severe effects on people's health. Droughts can also have negative impacts on the river basin's ecosystem (Kahil et al., 2015). During drought periods the navigability of the rivers is a severe problem for national and international companies as well as for the people living in this area (World Bank, 2014; Ministry of Transport, Htun Lwin Oo, personal communication, 2015). Most likely, water demand in Myanmar will increase in the future due to enhanced production and trade in agricultural products, the expansion of transport systems via rivers and ports, and the anticipated growth of cities and industries (World Bank, 2014). This increasing water demand and the high rainfall variability in the dry zone will probably cause the construction of more pumping stations for both groundwater and river water as well as the building of more reservoirs and dams.

\subsubsection{Cyclones}

The coast and the delta zones of the Ayeyarwady and Chindwin rivers are extremely exposed to impacts from cyclones associated with winds, storm surges and saltwater intrusion into groundwater (Rao et al., 2013). The Ayeyarwady Division is, compared to other regions in Myanmar, densely populated (177 km² ; Department of Population, 2015), and the extensive and shallow continental shelf of the Andaman Sea allows cyclones and storm surges to inundate the delta and some inbound areas (Webster, 2008). Tropical cyclone formation in the northern Indian Ocean occurs preferentially before (April-May) and directly after (October-November) the Asian summer monsoon season (Webster, 2008). During cyclone Nargis in the year 2008, which was the most devastating cyclone to strike Asia since 1991, the Ayeyarwady River delta region was flooded by a $3.5 \mathrm{~m}$ wall of water (Thomson Reuters, 2009). Wind speed was in excess of $65 \mathrm{~m} \mathrm{~s}^{-1}$ (Webster, 2008). More than 130000 people died and 2.4 million people were severely affected (van Driel and Nauta, 2013; Thomson Reuters, 2009). Nargis caused severe harm to the winter rice crop and loss of rice seed, and Myanmar faced food shortages after the event (Webster, 2008). Seawater inundated large areas of the Ayeyarwady delta, posing challenges to future rice production (Webster, 2008). Lin et al. (2009) detected a pre-existing warm ocean anomaly 
in the Bay of Bengal which was probably the reason why a weak category-1 storm could rapidly intensify to an intense category-4 storm within only $24 \mathrm{~h}$. Mangrove clearance for shrimp farms and rice paddies was probably a major factor in aggravating the impacts of cyclone Nargis (Nature News, 2008). Historically seen, Myanmar has only infrequent tropical cyclone landfalls, but since 2006 , there has been an apparent increased activity in the Indian Ocean. Whether this development is part of a continuing trend due to climate change is difficult to assess because data quality and length of the records are limited (Webster, 2008).

\subsection{Flora and fauna}

Myanmar is one of the few countries in South-east Asia with relatively high levels of biodiversity and intact forest areas (Rao et al., 2013). About $48 \%$, or $317730 \mathrm{~km}^{2}$, of Myanmar's surface is covered by closed tropical forest; however, according to the FAO, both quantity and quality are decreasing (Htun, 2009). In the early 1990s, Myanmar still had a total forest cover of about $442000 \mathrm{~km}^{2}$, which is $67 \%$ of the total surface area (Leimgruber et al., 2005). The forest flora ranges from sub-alpine to tropical formations (Aung, 2002). The forest along the Salween River on the Thai-Burmese border lies on a bio-geographic border that is rich in biodiversity, wildlife and fish populations, and this area is one of the most fertile areas for teak in the world (Salween Watch and SEARIN, 2004). Tropical evergreen rainforests occur in areas receiving $>2000 \mathrm{~mm}$ of rain annually, and they are home to many bird species. Many wild animals which were once plentiful are now reduced in number and are protected, e.g. the Irrawaddy dolphin, the Asian two-horned rhinoceros, the wild water buffalo, the gaur and other deer species (Hadden, 2008; Smith et al., 2009; Aung et al., 2013).

All species play an important role in maintaining balance in and supporting ecosystems. If these significant values and benefits are lost, humans will respond with additional inputs to maintain the system's functionality (Allen et al., 2010). The majority of threats to Myanmar's biodiversity are in general linked to human population growth and economic development, and the corresponding increasing demand for natural resources and space (Allen et al., 2010). Overexploitation of fish is a major concern for the country's inland fisheries, which is likely to increase due to political and economic transitions (Rao et al., 2013). However, little is known about species-ecosystem interactions to be sure of human (e.g. dam projects, mining) or climate impacts (e.g. temperature changes may lead to alien species invasions). Following Allen et al. (2010), alien species invasions, pollution from mining activities, river flow modifications and overexploitation of fish are the major threats to the biodiversity of freshwater systems in Myanmar.

\section{Social and economic features}

\subsection{Agricultural land use}

Agriculture is the main pillar of the country's economy and contributes $\sim 37 \%$ to the GDP (Ministry of Forestry of the Union of Myanmar, 2005; CIA, 2015). The estimated cultivated area in Myanmar is 18.27 million ha, which is equivalent to $55 \%$ of the cultivable area (FAO, 2015). More than $65 \%$ of the population live in rural areas, working in the agricultural sector (FAO, 2014). The major agricultural products are rice, pulses, beans, sesame, groundnuts, sugarcane and hardwood; $42 \%$ of Myanmar's cropland is cultivated with paddy rice, particularly in the Ayeyarwady delta region (FAO, 2014). The delta areas and river mouths are the most populated sections within the river basins. Here, cultivation of rice in flooded paddies predominates (FAO, 2014). In general, the agricultural practices are still very low tech, and usually water buffalos are used for ploughing (van Driel and Nauta, 2013). The majority of the farmers there are smallscale landholders with an average lot size of 2.27 ha cultivating paddy fields during the monsoon season and vegetable gardens on the river banks in the dry season (Salween Watch and SEARIN, 2004). All year they cast for fish in the rivers and along the coasts. The country has the largest estimated number of small-scale fisheries in the world (SEAFDEC, 2012). The government is the ultimate owner of all land in Myanmar and the farmers are only allowed to cultivate the land with the government's permission. One-third of the rural residents are landless labourers (Hiebert, 2012). Landgrabbing and confiscation by the military, government and international investors are a huge problem, particularly in the Tanintharyi region, followed by Kachin State (Farmlandgrab.org, 2014).

The mangrove forests in the delta and coastal areas supply firework and bark for tanning, which has already led to critical degradation of the ecologically important mangrove forests (Webb et al., 2014). The Ministry of Forestry of the Union of Myanmar (2005) estimated that the mangrove forest area decreased to about almost half of its size between 1990 and 2002. This development is likely going on due to the increasing number of fish and prawn ponds, salt evaporation ponds for commercial purposes and the expansion of agriculture land for food security (Ministry of Forestry of the Union of Myanmar, 2005).

The following categories of farmland exist in the country (JICA, 2013, p. 9): (1) paddy field or wetland which can be used for paddy farming (so-called Le), (2) upland farming (Yar), (3) farmland which appears in the floodplain in the Ayeyarwady River as the water recedes (Kaing), and (4) farmland which appears on the sandbars in the Ayeyarwady River as the water recedes (Kyun) (Fig. 2). Farming on flood plains and sandbars of the Ayeyarwady River is of interest due to the relatively good conditions of fertility and access to water for irrigation either directly from 
the river or from shallow groundwater aquifers. In contrast to the rainfed upland farms, where the groundwater aquifer is drawn out by tube wells, exploitation of water for irrigation is much easier and less costly.

We identified via remote sense analysis that in 2016 roughly $8 \%$ of the area in the central dry zone is alluvial farming land. The amount of farmland used for alluvial farming increased slightly from $1988\left(3855 \mathrm{~km}^{2}\right)$ to 2016 $\left(5512 \mathrm{~km}^{2}\right)$ from 5.6 to $8 \%$ of the total dry zone area. The alluvial land can be used as farmland only during and after the raining season, thus there is only a short cultivation period.

About $22 \%$ of the annual paddy production of Myanmar is generated within the central dry zone (McCartney et al., 2013). Furthermore, $89 \%$ of Myanmar's sesame production, $69 \%$ of the groundnut production and $70 \%$ of the country's sunflower production are generated within this area (McCartney et al., 2013). Pulses and cotton are other important crops in this region.

\subsection{Water use and management}

Myanmar has abundant water resources, including both surface water and groundwater. The potential water resource volume is estimated to be about $1000 \mathrm{~km}^{3}$ for surface water and about $500 \mathrm{~km}^{3}$ for groundwater (WEPA, 2014; Oo, 2015). The country's total renewable water resources are $24352 \mathrm{~m}^{3} \mathrm{yr}^{-1}$ per inhabitant, but only $5 \%$ of its physical water resources are used at present (WEPA, 2014). Water utilisation for the agricultural sector is about $90 \%$, while industry and domestic use is only about $10 \%$ of the total water use. Due to ongoing and expected future economic development and population growth, it is obvious that the physical potential for further development of water resources is substantial (WEPA, 2014).

Several national ministerial departments are responsible for the coordination of water-related issues in Myanmar. There is the Department of Irrigation, the Water Resources Utilisation Department, the Ministry of Rural Development (domestic water), the Ministry of Environmental Conservation and Forestry (MOECAF), and the Department of Meteorology and Hydrology and the Directorate of Water Resources and River Improvement, both associated with the Ministry of Transport.

\subsubsection{Central dry zone}

Farming in the central dry zone is only possible with irrigation due to the high variability of rainfall. Irrigation in the dry zone has its beginning in the 11th century when weirs and tanks were constructed. The first groundwater and surface water pumped systems were initiated in 1962 and they significantly contribute to increased food security in the central dry zone (McCartney et al., 2013). The annual recharge of groundwater in the dry zone is estimated around $4770 \mathrm{Mm}^{3}$ and the annual total use is $>770 \mathrm{Mm}^{3}$ (data from 2000; Johnston et al., 2013). In this region, irrigation is mainly conducted by canal systems from the rivers to the arable land, while groundwater withdrawal still plays a minor role. However, the number of pumping systems is increasing, particularly through Chinese investments (R. Johnston, personal communication, 2015). Rainwater harvesting and storage is another simple and common method for domestic and livestock purposes in the villages. During the dry season, village ponds dry out frequently. This problem is often solved by groundwater or river water pumping to the ponds (Johnston et al., 2013), which is in some regions conducted by the local government, which sells the water to the villagers (personal communication from a resident in Bagan, 2016).

\subsubsection{Ayeyarwady delta area}

Embankments, sluice gates and drainage systems have been constructed to protect the agricultural land in the lower delta against saltwater intrusion (van Driel and Nauta, 2013). During the monsoon season, rainwater is stored in drainage canals for the dry period. The gates of the sluices are kept open from mid-May to mid-September in order to control the water level of the drainage canal. Old river courses function as major drainage canals, but there are also smaller artificial drainage channels (van Direl and Nauta, 2013). Although these drainage systems have been quite proven for a long time, intrusion of saline water is a major concern in this area because of leakages, dam failures or natural hazards such as storm surges and cyclones. During the dry season, irrigation is practiced in the delta by pumping the water from the channels to the paddy fields. In the middle part of the delta, tidal irrigation is extensively practiced and possible due to sufficient flow of river water to the ocean (van Driel and Nauta, 2013).

\subsection{Hydropower and river flow modifications}

Myanmar's major rivers are still less regulated compared to other Asian rivers (Hedley et al., 2010). There are currently no dams on the mainstream of the Ayeyarwady River. However, about $1300 \mathrm{~km}$ of embankments were built during the late 19th and early 20th centuries (Hedley et al., 2010). Between 1988 and 2003, the government of Myanmar constructed about 150 smaller dams and reservoirs and 265 river water pumping stations along the tributaries (Ministry of Forestry of the Union of Myanmar, 2005). The Ayeyarwady River is subject to numerous potential dam projects, and seven dams are currently in the planning stage (Allen et al., 2010). Several dams are also planned along the Salween River, which likely will impact both the hydrodynamic and sediment load (Salmivaara et al., 2013). In 2011, planned hydropower dam constructions by the China Power Investment Corporation near Myitsone at the confluence of the Mali and N'Mai Rivers (Fig. 2) were halted due to peaceful public 
protests as well as armed resistance (Burma Rivers Network, 2014). The dam was intended to be built $152 \mathrm{~m}$ high, and it was envisaged as inundating 47 villages and displacing ca. 10000 people in Kachin State (Burma Rivers Network, 2014). Another critical point is that the northern part of the country is prone to earthquakes, and a broken dam would have catastrophic impacts on downstream areas and the city of Myitkyina, the capital of Kachin State (Burma Rivers Network, 2014). It is expected that building larger dams will come along with social impacts like displacements, food security, health concerns, and the loss of culture (Smakhtin and Anputhas, 2006; Burma Rivers Network, 2014). Myanmar has experienced a rapid growth of hydropower capacity with a potential of almost $40000 \mathrm{MW}$, of which only $6 \%$ have been developed. Hydropower supplies the majority of the electric exports supported by foreign investments (ADB, 2012; Kattelus et al., 2014).

River flow modifications lead to changes in the composition and diversity of aquatic communities. Aquatic species have evolved life history strategies primarily in response to the natural flow regimes. Therefore, flow regime alterations can lead to loss of biodiversity of native species (Smakhtin and Anputhas, 2006). Dam building results in a range of upstream and downstream impacts, not least disruption of migratory routes and of breeding patterns (Nilsson et al., 2005). Water abstraction and damming are one of the major threats to freshwater biodiversity (Allen et al., 2010). In the deltas, mangrove forests rely on the non-saline water from rivers. Any reduction in the volume of sweet water to their roots causes mangroves to dry up, resulting in saltwater intrusion and subsequent soil erosion. It is further assumed that the construction of dams would accelerate the deforestation in the Salween River basin, with severe negative effects on biodiversity and the dense dry deciduous forests, also called teak forest, which are crucial for the livelihood function of local ethnic people (Salween Watch and SEARIN, 2014). In general, the full scope and scales of potential environmental and ecological impacts from dams is largely uncertain due to the complexity of feedback mechanisms and system responses (Fan et al., 2015), particularly in regions where the rivers play such an important role like in Myanmar. Dams will alter the river flows as well as the sediment load, which will impact the further development of the Ayeyarwady delta. For the navigability of the rivers and the canals, a decrease in the sediment load would be a favourable effect of dam building.

China has an increasing interest in covering its energy demand due to being forced by the international community to get out of $\mathrm{CO}_{2}$-emission intensive power generation. Making investments in hydropower in Myanmar in order to provide energy for the western part of China solves these challenges for now. At first glance, both nations benefit from this energy trade. Building dams could potentially increase the irrigation opportunities, particularly in the central dry zone of Myanmar. It would enhance navigation possibilities and provide flood control (Lu et al., 2014). On the one hand, the energy trade is an economic and political opportunity because it must be based on cooperation between Myanmar and its neighbouring countries and counters the isolation status which is partly still existent (Kattelus et al., 2015). On the other hand, damming Myanmar's rivers could have very serious negative effects on the river biodiversity and the stability of the deltas (Hedley et al., 2010). A decreasing supply of the fertile alluvial sediments would modify the availability of agricultural land to an unknown extent. It is expected that deforestation would further increase in the dam building areas as a result of infrastructure plans, with severe impacts on local biodiversity, local people, hydrology and on regional and even global climate.

India, Bangladesh, China and Thailand have different interests in Myanmar's water resources and all of them are involved in diverse hydropower project plans. These natural resources as well as Myanmar's convenient geographical and strategic geopolitical location will possibly strengthen the country's economic and political role in South-east Asia. Negative aspects of hydropower development are the risk of rising conflicts between ethnic minorities and the military (Burma Rivers Network, 2014) and also between Myanmar and neighbouring countries due to differing interests and needs of the water resources.

\subsection{River ecology protection}

All aspects of water resource conservation are unified in the Conservation of Water Resources and Rivers Law, enacted in 2006. It aims to conserve and protect all water resources and river systems for beneficial utilisation by the public, to protect the environment, to smoothen and make safe waterway navigation along rivers and creeks and to contribute to the development of the state economy by improving water resources and the river system (Union of Myanmar, 2006). Mining within $100 \mathrm{~m}$ of the Ayeyarwady, Salween, Chindwin and Sittaung rivers is banned by the Ministry of Mines (Schmidt, 2012). However, despite these ambitious laws, freshwater diversity, including inland wetlands, estuaries and mangroves, appears to be limitedly protected in Myanmar (Salmivaara et al., 2013).

In 2013, a National Water Resources Committee (NWRC) was established by a presidential decree. The NWRC stated that the weak cooperation between the water-related agencies in Myanmar is the major problem (Win, 2014). The committee follows the vision that "In 2020 Myanmar will become water efficient nation with well developed and sustainable water resources based on fully functional integrated water resources management system" (Win, 2014). The NWRC concludes that more research is needed to solve the problems in Myanmar's river basins (Win, 2014). 


\section{Climate change impacts and future perspectives}

Only a very few studies on climate change impact assessments in Myanmar have been conducted so far (Shrestha et al., 2014). During the past decades, inter-seasonal, interannual and spatial variability in rainfall has been observed across all South-east Asian countries (IPCC, 2014). However, detailed studies for Myanmar in particular are lacking, but a similar pattern can be assumed due to the influence of the same monsoonal atmospheric circulation system. A substantial inter-decadal variability exists in the Indian monsoon circulation which is particularly crucial for the central dry zone (IPCC, 2014). Extreme weather events have become more frequent and intense during the last decades, related to their direct impacts on socio-economy, which could also be detected for Myanmar (GCCA, 2012). Most likely, the intensity and frequency of droughts in the dry zone, particularly during ENSO events, will increase (IPCC, 2014). Variability of river runoff and changes in seasonality are expected for South-east Asia as a result of climate change (IPCC, 2014). Sea-level rise, decreasing river runoff and increasing intensity and frequency of droughts will lead to even more increased saltwater intrusion into river deltas. In the medium term, enhanced glacier melt and snowmelt in the source areas of rivers will cause generally higher discharges and potential floods. However, individual glaciers are currently advancing or stable in Asia, depending on their particular features (Scherer et al., 2011). Studies on the glaciers feeding the Ayeyarwady have not been conducted yet. The low-lying Ayeyarwady delta is particularly exposed to sea-level rise and vulnerable due to its high food productivity and population density. It is assumed that a $0.5 \mathrm{~m}$ sea-level rise would advance the shoreline along the Ayeyarwady delta by $10 \mathrm{~km}$ inland (NAPA, 2012). Changes in river flow will likely increase the risk of flash floods and lowland regions will be regularly inundated (NAPA, 2012). Furuichi et al. (2009) showed a decrease in the annual discharge of the Ayeyarwady River over the last 100 years based on a statistical comparison with data collected in the 19th century, but the driving forces remain unclear. The central dry zone experienced higher maximum temperatures and less rainfall in the 1990s compared to other regions in Myanmar (Ministry of Forestry of the Union of Myanmar, 2005). This is hypothesised to be a result of anthropogenic climate change and global warming (Ministry of Forestry of the Union Myanmar, 2005). Increasing temperatures in this region will raise the concentration of dissolved salts in the ponds, channels and other storage systems, resulting in a reduction of drinking water (NAPA, 2012).

Climate change is expected to exacerbate existing threats to biodiversity in Myanmar through its impacts on humans and their dependence on products and services produced by freshwater ecosystems (Rao et al., 2013). Changes in rainfall regimes, air and water temperature and evapotranspiration will affect distribution and abundance of freshwater species in unknown ways (Rao et al., 2013). Particularly the
Ayeyarwady River basin will most likely be affected by population growth, urbanisation, land use change and climate change in the future (Bates et al., 2008; Salmivaara et al., 2013). Rao et al. (2013) concluded, based on findings from Iwamura et al. (2010), that the Ayeyarwady dry forest located in the central river basin is particularly prone to future changing rainfall and temperature conditions. The authors expect that the seasonal amount of rainfall will decrease, which will exacerbate the already water-stressed region (Rao et al., 2013).

Continuing loss of natural forest cover and mangrove habitats can influence processes affecting climate change by release of $\mathrm{CO}_{2}$ into the atmosphere (Van der Werf et al., 2009). It can be summarised that climate change most likely will impact the river basin ecosystems in Myanmar to a so-far unknown extent through modification of seasonal flow regimes and the timing, extent and duration of floods and droughts. Climate change projections and scenarios have not yet been developed for Myanmar in particular. There are numerous assumptions and expectations but no detailed data for the country. This lack of future assessments is also a result of the nonexistence of paleoclimate data.

Due to the lack of scientific research in the country, often uncertain or incomplete databases and rapid political and economic changes, future perspectives for human-water dynamics in Myanmar's river basins can only be assessed with high uncertainties. However, it should be possible to indicate the major drivers of future changes. Undoubtedly, the availability and quality of freshwater is and will be the core of the country's future development, but increasing conflicts on water may arise due to growing foreign investments and various international and national interests.

Findings from Salmivaara et al. (2013) indicate that the Ayeyarwady delta, the Salween River mouth and the central lowlands in the Ayeyarwady River basin are under the highest pressure as a result of intensive land use, high population density and vulnerability to water pollution. These regions are most likely to be exposed to further pressures such as urbanisation, land use change and climate change (Bates et al., 2008). Major challenges for the Salween River basin will be linked to extensive dam projects (Burma River Networks, 2014; Kattelus et al., 2014). The major challenges for Myanmar are seen in covering the balance between national societal, economic and political development and the urgent need to protect and conserve its water resources and biodiversity.

\section{Selection and identification of human-water dynamic key indicators}

Human-water dynamics include one-way causal chains as well as complex feedback mechanisms. Particularly in a country like Myanmar where water plays such a major role in people's lives, detailed knowledge and understanding of human-water interactions are essential in order to evaluate 
Table 1. Selection of general indicators within the DPSIR framework. Respective responses are not listed because they are the subject of our future research and will be studied more in detail.

\begin{tabular}{|c|c|c|c|c|c|c|}
\hline $\begin{array}{l}\text { Driving } \\
\text { force }\end{array}$ & Energy demand & $\begin{array}{l}\text { Land use } \\
\text { intensification }\end{array}$ & \multicolumn{2}{|c|}{ Increase in atmospheric $\mathrm{CO}_{2}$} & Industrialisation & $\begin{array}{l}\text { Demand for } \\
\text { wood/wood } \\
\text { trade }\end{array}$ \\
\hline Pressure & $\begin{array}{l}\text { Building } \\
\text { hydropower } \\
\text { dams }\end{array}$ & $\begin{array}{l}\text { Increase in water } \\
\text { withdrawal and } \\
\text { groundwater } \\
\text { pumping }\end{array}$ & \multicolumn{2}{|c|}{$\begin{array}{c}\text { Increase in temperature and } \\
\text { evaporation }\end{array}$} & $\begin{array}{l}\text { Polluted } \\
\text { sewage release }\end{array}$ & Deforestation \\
\hline State & $\begin{array}{l}\text { Change in river } \\
\text { flow }\end{array}$ & $\begin{array}{l}\text { Decrease in } \\
\text { groundwater level }\end{array}$ & $\begin{array}{l}\text { Change in } \\
\text { precipitation } \\
\text { (monsoon) } \\
\text { patterns }\end{array}$ & $\begin{array}{l}\text { Increase in } \\
\text { glacier melt }\end{array}$ & $\begin{array}{l}\text { Deterioration of } \\
\text { water quality }\end{array}$ & $\begin{array}{l}\text { Soil } \\
\text { degradation }\end{array}$ \\
\hline Impact & $\begin{array}{l}\text { Biodiversity } \\
\text { Fish migration }\end{array}$ & $\begin{array}{l}\text { Shortage of } \\
\text { groundwater }\end{array}$ & $\begin{array}{l}\text { Longer dry } \\
\text { periods, } \\
\text { droughts, higher } \\
\text { maximum } \\
\text { temperatures }\end{array}$ & $\begin{array}{l}\text { Seasonal } \\
\text { shift in river } \\
\text { discharge } \\
\text { Agriculture, } \\
\text { biodiversity }\end{array}$ & $\begin{array}{l}\text { Availability of } \\
\text { water in good } \\
\text { quality for } \\
\text { humans and } \\
\text { agricultural use, } \\
\text { biodiversity }\end{array}$ & $\begin{array}{l}\text { Increase in } \\
\text { erosion } \\
\text { processes } \\
\text { and sediment } \\
\text { load in the } \\
\text { rivers }\end{array}$ \\
\hline
\end{tabular}

possible future developments. This knowledge is crucial for a proper and sustainable water management that meets the social, environmental, economic and political interests. Our first step for future human-water dynamic studies in Myanmar is therefore the selection and identification of environmental key indicators based on the reviewed literature within the paper presented here and based on our own observations during field studies. Environmental key indicators provide information on complex issues in a simplified manner and characterise major causal impact-response chains. They can be used for future development assessments and current state analyses.

For the study presented here, the eDPSIR (enhanced driving force-pressure-state-impact-response) concept by Niemeijer and de Groot $(2008 \mathrm{a}, \mathrm{b})$ is seen as a suitable framework to structure the selection of relevant environmental indicators. This framework is an enhancement of the DPSIR (driving force-pressure-state-impact-response) approach which has been applied to several water-related environmental studies in order to identify causal chains (e.g. Pirrone et al., 2005; Kagalou et al., 2012; Pinto et al., 2013; Geng et al., 2014). The advantage of an enhanced DPSIR application is that this framework is causal network based and includes the interrelations and feedbacks between various causal chains within a system. First, we follow the steps to build a causal network proposed by Niemeijer and de Groot (2008a).

- Step 1: broadly define the domain of interest: humanwater interactions in Myanmar's river basins.

- Step 2: determine boundary conditions: sociohydrological systems in the humid tropics, monsoon influenced.
- Step 3: determine the boundaries of the system: in situ situation in the river basins with particular focus on the Ayeyarwady River basin.

- Step 4: identification of abstract indicators of the main factors and processes (Table 1): energy needs, land use intensification, increase in atmospheric $\mathrm{CO}_{2}$, global warming, expansion of industrial zones and demand for wood are examples of driving forces in Myanmar's river basins. These drivers create pressures which in turn modify the state of e.g. river discharge, soil degradation, water quality, and so on. Changes in the state of e.g. water quality impact aquatic biodiversity and the availability of drinking water. The last row, responses, has been omitted since this aspect is not the focus of this paper, and particular responses of the society or government have to be studied in the future in more detail.

- Step 5: iteratively mapping the indicators in a direction graph: Fig. 3 shows a causal network of selective indicators for human-water interactions in Myanmar. There is no claim for completeness regarding the specific links and feedbacks. It is a first attempt to structure the relationships between and within water-related social and physical-environmental indicators in Myanmar's river basins.

Figure 3 demonstrates the complexity of a causal network of indicators for human-water dynamics in Myanmar. Mapping this network helps to identify important nodes and to structure further study approaches. Runoff for example seems to be an important end-of-chain node (cf. Niemeijer and de Groot, 2008a, b), as well as fish population, which is indicated by many incoming arrows, whereas dam and reservoir 


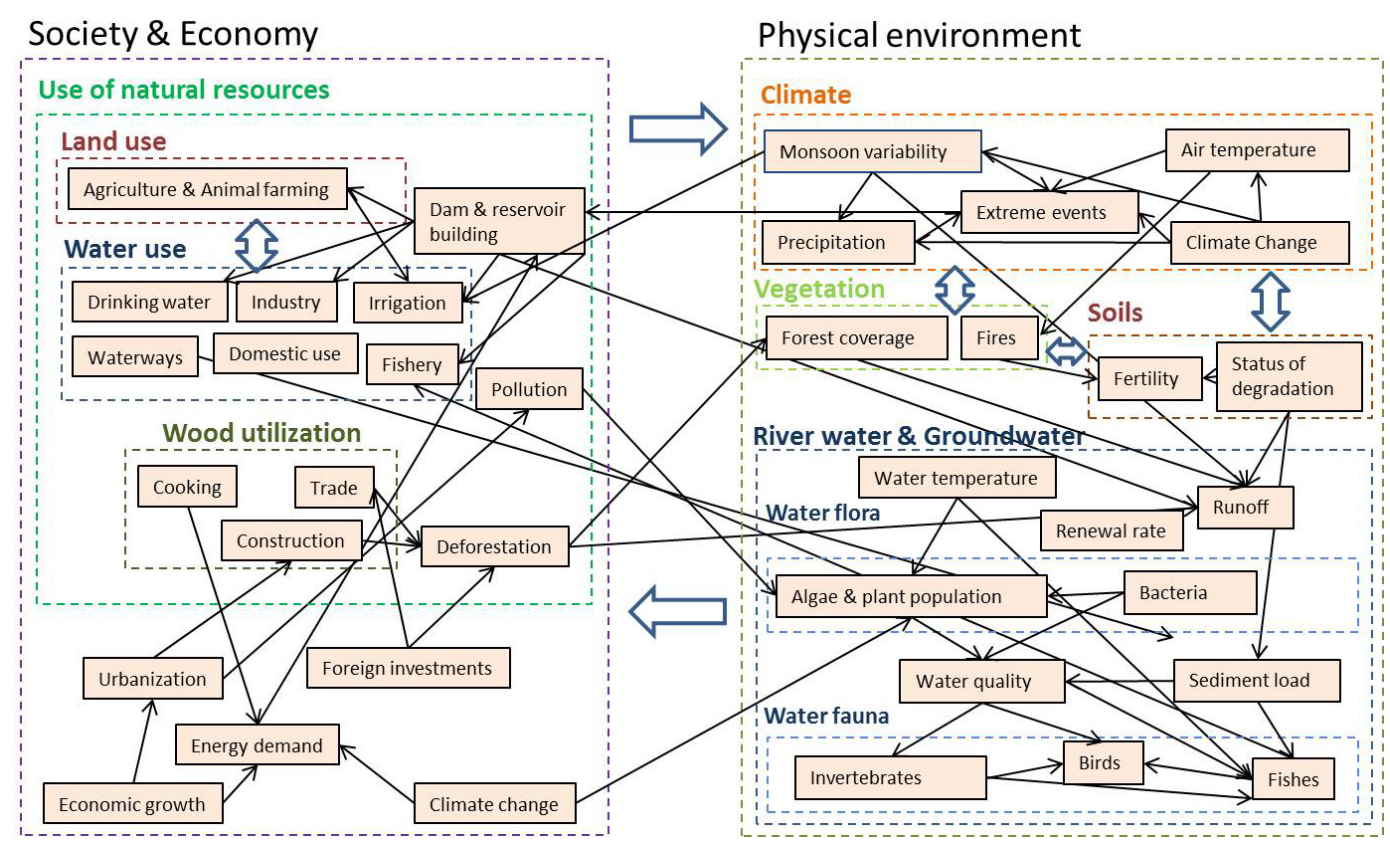

Figure 3. A causal network to demonstrate specific (thin black arrows) and general (large blue arrows) links between and within water-related social and physical-environmental indicators in Myanmar's river basins.

building and deforestation represent a central node with several incoming and outgoing arrows. It is challenging to identify a typical root node indicated by many outgoing arrows. Climate change might be a root node within this network. It is undoubtedly triggered by human activities, though rather on a larger spatial scale, and the impact of the Burmese people on global climate change is comparatively small, at least at the current state.

Furthermore, Fig. 3 clearly shows that studying humanwater interactions essentially needs the input from social as well as from natural sciences, and it is indispensable that experts from both disciplines exchange their knowledge and work together on the same research questions.

\section{Alluvial farming as an example of human-water dynamics within the Ayeyarwady River basin}

Alluvial farming can be seen as a demonstrative example of human-water dynamics in the dry zone of Myanmar. Assuming that climate variability in terms of (monsoon) precipitation variability is one of the root-node indicators of human-water dynamics in Myanmar, changes in precipitation amounts or timing cause high hydromorphological and sedimentation dynamics in the Ayeyarwady River. Lower rainfall amounts or dry periods result in lower river discharge and foster the accumulation of sandbars in the river bed. Moreover, land use changes and forest logging have an additional influence on sedimentation loads in the river and create new fertile floodplains. Most likely, these processes have a visible impact on alluvial farming in the dry zone be- cause more fertile arable land with good access to irrigation water is available. This is of even higher importance in the light of an increase in dry spells and changed timing of the monsoon rain in the dry zone. Our remote sensing analysis shows an increase in alluvial farming by $1657 \mathrm{~km}^{2}$ (almost $43 \%$ ) since 1988. Most of the alluvial farmers grow crops like onions because of market prices, suitability to alluvial land, and short-term benefits (personal communication with citizens of the dry zone). Concurrently, small-scale alluvial farming implies a potentially higher flood risk and related crop failure and loss of yields for the farmers and livelihoods of their families and communities. However, whether and how these observations are actually an impact chain has to be investigated and is the subject of further research.

\section{Conclusions}

Myanmar's economy and the people's income and wellbeing strongly depend on the quality and availability of sufficient water resources. The delta region of the Ayeyarwady River and the central dry zone are the areas most populated and most intensely used by agriculture in the country. On the one hand, the farmers depend on frequent river flood events because the river provides fertile alluvial soils; on the other hand, they suffer from water-related extreme events such as floods or drought periods. It is expected that theses climatic extreme events will likely increase in frequency and magnitude in the future as a result of climate change. Different national and international interests in the abundant water resources may provide opportunities and risks at the same time 
for Myanmar. Several dam projects along the main courses of the major rivers are currently in the planning phase. Dams will most likely modify the river flows, the sediment loads and also the still rich biodiversity in the river basins, to a still unknown extent. On the other hand, these foreign investments allow the development of infrastructure and probably stabilise the political relations between Myanmar and its neighbouring countries and strengthen its role in South-east Asia and even globally.

All authors of the reviewed literature agree that Myanmar is facing big water-related challenges. However, future perspectives and developments are mostly still intangible due to the large gap of research in the country and the limited detailed knowledge about the status quo. More in-depth qualitative and especially quantitative analyses of human and climate impacts on Myanmar's water resources are strongly required in order to adapt water and land management to current and future climate change. The year 2008 was a kind of turning point, when cyclone Nargis made landfall in the Ayeyarwady delta region. Since then, a number of action plans have been established with the aim of calling attention to extreme weather events. Furthermore, the vulnerability of the Burmese people is increasing because population pressure is forcing more people to live and work in coastal zones and river basins. The central dry zone and the delta zone are the most vulnerable parts of the river basin related to climate change and also to human impact.

Relevant aspects for future development of Myanmar's river basins combine environment-water-related indicators, climate, economic and social development, water management and land use changes. Research on these interplays needs to capture the spatial and temporal dynamics of these drivers. However, it is only possible to gain a full understanding of all these complex interrelationships when multiscale spatiotemporal information is analysed in an inter- and trans-disciplinary approach. The eDPSIR approach is considered to be a suitable starting point for human-water research in Myanmar. The indicator scheme presented here (Fig. 3) was a first attempt to structure the reviewed information and to provide a first assessment of relevant indicators and key nodes on the socio-economic as well as physical sides. Alluvial farming is a suitable example of human-water dynamics in Myanmar's central dry zone and it could be demonstrated that the share of alluvial farmland increased by $70 \%$ since 1988 in this region. We hypothesise that the increase in alluvial farming is an effect of hydromorphological impacts (potentially enhanced by human interventions like forest clearing). Concurrently this land is largely used because of relatively good farming conditions (fertile soils and good access to water for irrigation) compared to upland farmland in the central dry zone, especially in light of the difficult climate conditions. However, increased alluvial farming increases the potential flood risk for the farmers' livelihoods. However, this hypothesis has to be investigated in further studies.
Acknowledgements. The authors are grateful to Stephan Opitz (University of Cologne) and Henrik Bours (University of Bonn), whose critical comments helped to improve the manuscript. Adrian Almoradie (University of Bonn) assisted in the preparation of the overview map. Furthermore, we thank Mukesh Boori (Samara State Aerospace University Russia) for the remote sensing analysis on alluvial farmland. The research was funded by the German Science Foundation (DFG). The authors would like to thank three anonymous reviewers for their useful comments on earlier versions of this paper.

Edited by: T. Bogaard

Reviewed by: W. Win Zin and two anonymous referees

\section{References}

ADB - Asian Development Bank, Myanmar in transition, Opportunities and challenges, http://www.adb.org/sites/default/files/ publication/29942/myanmar-transition.pdf (last access: 15 October 2015), 2012.

Allen, D. J., Molur, S., and Daniel, B. A.: The status and distribution of freshwater biodiversity in the Eastern Himalaya, UCN, Cambridge, UK and Gland, Switzerland, and Zoo Outreach Organisation, Coimbatore, India, 2010.

Aung, M. M.: State of forests and forest genetic resources in Myanmar, Proceedings of the Southeast Asian Moving Workshop on Conservation, Management and Utilization of Forest Genetic Resources, edited by: Koskela, J., Appanah, S., Pedersen, A. P., and Markopoulos, M. D., Forestry Research Support Programme for Asia and the Pacific (FORSPA), FORSPA Publication No. 31/2002, Food and Agriculture Organization of the United Nations (FAO), June 2002, Bangkok, http://www. fao.org/docrep/005/ac648e/ac648e00.htm\#Contents (last access: 15 September 2015, 2002.

Aung, T. T., Mochida, Y., and Than, M. M.: Prediction of recovery pathways of cyclone-disturbed mangroves in the mega delta of Myanmar, Forest Ecol. Manage., 293, 103-113, 2013.

Bates, B., Kunddzewicz, Z. W., Wu, S., and Palutikof, J. (Eds.): Climate change and water, Vol. VI, Technical Paper of the Intergovernmental Panel on Climate Change, IPCC Secretariat, Geneva, 2008.

Bender, F.: Geology of Burma. Beiträge zur regionalen Geologie der Erde, Gebrüder Borntraeger, Berlin, Stuttgart, 311 pp., 1983.

Bird, M. I., Robinson, R. A. J., Win Oo, N., Maung Aye, M., Lu., X. X., Higgitt, D. L., Swe, A., Tun, T., Lhain, S., Win, K., Sandar Aye, K., Mi Mi Win, K., and Hoey, T. B.: A preliminary estimate of organic carbon transport by the Ayeyarwady (Irrawaddy) and Thanlwin (Salween) Rivers of Myanmar, Quatern. Int., 186, 113 122, 2008.

Burki, T.: Floods in Myanmar damage hundreds of health facilities, Lancelet, 386, 843, 2015.

Burma Rivers Network: http://burmariversnetwork.org/ (last access: 25 August 2015), 2014.

CIA - Central Intelligence Agency, The World Factbook, Burma, https://www.cia.gov/library/publications/the-world-factbook/ geos/bm.html, last access: 13 October 2015.

Dai, A.: Drought under global warming: a review, WIREs Clim. Change, 2, 45-65, 2011. 
D'Arrigo, R. and Ummenhofer, C. C.: Short Communication. The climate of Myanmar: evidence for effects of the Pacific Decadal Oscillation, Int. J. Climatol., 35, 634-640, 2015.

D’Arrigo, R., Palmer, J., Ummenhofer, C. C., Kyaw, N. N., and Krusic, P.: Three centuries of Myanmar monsoon climate variability inferred from teak tree rings, Geophys. Res. Lett., 38, L24705, doi:10.1029/2011GL049927, 2011.

Department of Population: Ministry of Immigration and Population, The Republic of the Union of Myanmar, The 2014 Myanmar Population and Housing Census, The Union Report, Census Report Vol. 2, http://myanmar.unfpa.org/census (last access: 19 May 2016), 2015.

Di Baldassarre, G., Viglione, A., Carr, G., Kuil, L., Salinas, J. L., and Blöschl, G.: Socio-hydrology: conceptualising humanflood interactions, Hydrol. Earth Syst. Sci., 17, 3295-3303, doi:10.5194/hess-17-3295-2013, 2013.

DMH - Department of Meteorology and Hydrology Myanmar: Drought conditions and management strategies in Myanmar, http://www.ais.unwater.org/ais/pluginfile.php/597/mod_page/ content/79/Myanmar.pdf, last access: 17 September 2015.

Fan, H., He, D., and Wang, H.: Environmental consequences of damming the mainstream Lacang-Mekong River: A review, Earth-Sci. Rev., 146, 77-91, 2015.

FAO: aquastat, Salween river basin, http://www.fao.org/nr/water/ aquastat/basins/salween/salween-CP_eng.pdf (last access: 23 September 2015), 2011.

FAO: FAOSTAT on the UN, Myanmar, Food and Agriculture Organization of the United Nations (FAO), http://faostat.fao.org/ CountryProfiles/Country_Profile/Direct.aspx?lang=en\&area=28 (last access: 24 September 2015), 2014.

FAO: aquastat database, Food and Agriculture Organization of the United Nations (FAO), http://www.fao.org/nr/water/aquastat/ data/query/index.html?lang=en, last access: 1 September 2015.

FAO: 2015-2016 El Niño, Early action and response for agriculture, food security and nutrition, Report Working Draft (25 April 2016), Up date \#7, http://www.fao.org/fileadmin/user_upload/emergencies/ docs/FAOEarlyActionandResponse2015-2016EINinoReport_ SeventhUpdate_250416.pdf, last accdess: 20 May 2016.

Farmlandgrab.org: There is no voice of real farmers, http:// farmlandgrab.org/24313 (last access: 15 October 2015), 2014.

Furuichi, T., Win, Z., and Wasson, R. J.: Discharge and suspended sediment transport in the Ayeyarwady River, Myanmar: Centennial and decadal changes, Hydrol. Process., 23, 1631-1641, 2009.

GCCA - Global Climate Change Alliance, Myanmar climate change alliance, http://www.gcca.eu/national-programmes/asia/ gcca-myanmar (last access: 14 October 2015), 2012.

Geng, Q. L., Wu, P., Zhao, X. N., and Wang, Y. B.: A framework of indicator system for zoning of agricultural water and land resources utilization: A case study of Bayan Nur, Inner Mongolia, Ecol. Indicat., 40, 43-50, 2014.

Hadden, R. L.: The geology of Burma (Myanmar): An annotated bibliography of Burma's geology, geography and earth science, Topographic Engineering Center, Alexandria, Virginia, USA, 312 pp., 2008.

Hedley, P. J., Bird, M. I., and Robinson, R. A. J.: Evolution of the Irrawaddy delta region since 1850, Geogr. J., 176, 138-149, 2010.
Hiebert, M.: Land reform: A critical test for Myanmar's government, Southeast Asia from the Corner of $18^{\text {th }} \& \mathrm{~K}$ Streets, Center for Strategic \& International Studies, Chair for Southeast Asia Studies, Vol. III, http://csis.org/files/publication/ 121108_SoutheastAsia_Vol_3_Issue_21.pdf (last access: 15 October 2015), 2012.

Hirabayashi, Y., Mahendran, R., Koirala, S., Yamazaki, D., Watanabe, S., and Kanae, S.: Global flood risk under climate change, Nat. Clim. Change, 3, 816-821, 2003.

Htun, K.: Myanmar forestry outlook study. Asia-Pacific forestry sector outlook study II, Working Paper Series, Working Paper No. APFSOS II/WP/2009/07, Food and Agriculture Organization of the United Nations, Regional Office for Asia the Pacific, Bangkok, 2009.

Htway, O. and Matsumoto, J.: Climatological onset dates of summer monsoon over Myanmar, Int. J. Climatol., 31, 382-393, 2011.

IPCC: Climate Change 2014, Synthesis report, http://www.ipcc.ch/ pdf/assessment-report/ar5/syr/SYR_AR5_FINAL_full.pdf (last access: 13 October 2015), 2014.

Irrawaddy: Land: The search for solutions, Interview with Dr. Thaung Htun, http://www.irrawaddy.org/magazine/ land-search-solutions.html, last access: 15 October 2015.

Iwamura, T., Wilson, K. A., Venter, O., and Possingham, H. P.: A climatic stability approach to prioritizing global conservation investments, PLoS ONE, 5, e15103, doi:10.1371/journal.pone.0015103, 2010.

JICA - Japan International Cooperation Agency: Data collection survey on the project for development of water saving agricultural technology in the central dry zone in the Republic of the Union of Myanmar, Final report, Ministry of Agriculture and Irrigation, The Republic of the Union of Myanmar, available at: http://open_jicareport.jica.go.jp/pdf/12127163.pdf (last access 17 August 2016), 2013.

Johnston, R., Pavelic, P., Sellamuttu, S. S., and McCartney, M.: Water Management in the Dry Zone, Irrawaddy Basin, Myanmar IWMI Dry Zone Study, http://riversymposium.com/wp-content/ uploads/2014/10/A3A_Robyn-Johnson.pdf (last access: $31 \mathrm{Au}-$ gust 2015), 2013.

Kagalou, I., Leonardos, I., Anastasiadou, C., and Neofytou, C.: The DPSIR Approach for an Integrated River Management Framework. A Preliminary Application on a Mediterranean Site (Kalamas River - NW Greece), Water Resour. Manage., 26, 16771692, 2012.

Kahil, M. T., Dinar, A., and Albiac, J.: Modeling water scarcity and droughts for policy adaptation to climate change in arid and semiarid regions, J. Hydrol., 522, 95-109, 2015.

Kattelus, M., Rahaman, M. M., and Varis, O.: Myanmar under reform: Emerging pressures on water, energy and food security, Nat. Resour. Forum, 38, 85-98, 2014.

Kattelus, M., Rahaman, M. M., and Varis, O., Hydropower development in Myanmar and its implications on regional energy cooperation, Int. J. Sustain. Soc., 7, 42-66, 2015.

Kreft, S. and Eckstein, D.: Global Climate Risk Index 2014. Who suffers most from extreme weather events? Weather-related loss events in 2012 and 1993 to 2012, http://germanwatch.org/en/ download/8551.pdf (last access: 18 August 2015), 2014.

Kumar, K. K., Rajagopalan, B., and Cane, M. A.: On the weakening relationship between the Indian Monsoon and ENSO, Science, 284, 2156-2159, 1999. 
Leimgruber, P., Kelly, D. S., Steininger, M. K., Brunner, J., Müller, T., and Songer, M.: Forest cover change patterns in Myanmar (Burma) 1990-2000, Environ. Conserv., 32, 356-364, 2005.

Li, X. Q. and Ting, M. F.: Recent and future changes in the Asian monsoon-ENSO relationship: Natural or forced?, Geophys. Res. Lett., 42, 3502-3512, doi:10.1002/2015GL063557, 2015.

Lin, I.-I., Chen, C.-H., Pun, I.-F., Liu, W. T., and Wu, C.-C.: Warm ocean anomaly, air sea fluxes, and the rapid intensification of the tropical cyclone Nargis (2008), Geophys. Res. Lett., 36, L03817, doi:10.1029/2008GL035815, 2009.

Lu, X. X., Li, S., Kummu, M., Padawangi, R., and Wang, J. J.: Observed changes in the water flow at Chiang Saen in the lower Mekong: Impacts of Chinese dams?, Quatern. Int., 336, 145-157, 2014.

Lwin, Z.: Ayeyarwady Integrated River Basin Management Project, The Republic of the Union of Myanmar, Ministry of Transport, Directorate of Water Resources and Improvement of River Systems, http://www.inbo-news.org/IMG/pdf/13b-AIRBM_ PPT_16-10-2014_Lao_FINAL-Myanmar.pdf (last access: 23 September 2015), 2014.

Maung, M. K.: Forecasting the coastal rainfall of Burma, Q. J. Roy. Meteorol. Soc., 71, 115-125, 1945.

McCartney, M., Pavelic, P., Lacombe, G., Latt, K., Zan, A. K., Thein, K., Douangsavanh, S., Balasubramanya, S., Ameer, R., Myint, A., Cho, C., Johnston, R., and Sotoukee, T.: Water resource assessment of the Dry Zone of Myanmar, Final report for component 1, Project report of the Livelihoods and Food Security Trust Fund (LIFT) Dry Zone Program, International Water Management Institute (IWMI); Vientiane, Laos, National Engineering and Planning Services (EPS), Yangon, Myanmar, 52 pp., 2013.

Ministry of Forestry of the Union of Myanmar: National action programme of Myanmar to combat desertification in the context of United Nations convention to combat desertification (UNCCD), http://www.unccd.int/ActionProgrammes/ myanmar-eng2005.pdf (last access: 24 September 2015), 2005.

MOAI - Ministry of Agriculture and Irrigation, Union of Myanmar, http://myanmargeneva.org/e-com/Agri/expind/agri-index/ myanmar.com/Ministry/agriculture/default_1.html (last access: 27 August 2015), 2001.

Myanmar's National Adaptation Programme of Action (NAPA) to Climate Change, http://unfccc.int/resource/docs/napa/mmr01. pdf (last access: 13 October 2015), 2012.

Nature News: Forest clearance boosted power of cyclone Nargis, Nature, 453, 270, 2008.

Niemeijer, D. and de Groot, R. S.: A conceptual framework for selecting environmental indicator sets, Ecol. Indicat., 8, 14-25, 2008a.

Niemeijer, D. and de Groot, R. S.: Framing environmental indicators: moving from causal chains to causal networks, Environ. Dev. Sustain., 10, 89-106, 2008b.

Nilsson, C., Reidy, C. A., Dynesius, M., and Revenga, C.: Fragmentation and flow regulation of the world's large river systems, Science, 308, 405-408, 2005.

Oo, H. L.: Case study: Integrated water resources management in Myanmar, Abstract at UN-Water Annual International Zaragoza Conference 2015, http://www.un.org/waterforlifedecade/ waterandsustainabledevelopment2015/pdf/Htun_Lwin_oo_ MyanmarGDG.pdf, last access: 5 October 2015.
Oo, N. W.: Present state and problems of mangrove management in Myanmar, Trees, 16, 218-223, 2002.

Peel, M. C., Finlayson, B. L., and McMahon, T. A.: Updated world map of the Köppen-Geiger climate classification, Hydrol. Earth Syst. Sci., 11, 1633-1644, doi:10.5194/hess-11-16332007, 2007.

Pinto, R., de Jonge, V. N., Neto, J. M., Domingos, T., Marques, J. C., and Patrício, J.: Towards a DPSIR driven integration of ecological value, water uses and ecosystem services for estuarine systems, Ocean Coast. Manage., 72, 64-79, 2013.

Pirrone, N., Trombino, G., Cinnirella, S., Algieri, A., Bendoricchio, G., and Palmeri, L.: The Driver-Pressure-State-ImpactResponse (DPSIR) approach for integrated catchment-coastal zone management: preliminary application to the Po catchmentAdriatic Sea coastal zone system, Reg. Environ. Change, 5, 111137, 2005.

Postel, S. and Richter, B.: Rivers for life: managing water for people and nature, Island Press, Washington, D.C., 220 pp, 2003.

Rao, M., Htun, S., Platt, S. G., Tizard, R., Poole, C., Myint, T., and Watson, J. E. M.: Biodiversity conservation in a changing climate: A review of threats and implications for conservation planning in Myanmar, Ambio, 42, 789-804, 2013.

Robinson, R. A. J., Bird, M. I., Oo, N. W., Hoey, T. B., Aye, M. M., Higgitt, D. L., Lud, X. X., Swe, A., Tun, T., and Win, S. L.: The Irrawaddy river sediment flux to the Indian Ocean: the original nineteenth-century data revisited, J. Geol., 115, 629-640, 2007.

Salmivaara, A., Kummu, M., Keskinen, M., and Varis, O.: Using global datasets to create environmental profiles for data-poor regions. A case from the Irrawaddy and Salween river basins, Environ. Manage., 51, 897-911, doi:10.1007/s00267-013-0016-x, 2013.

Salween Watch and SEARIN - Southeast Asia Rivers Network: Center for Social Development Studies Chulalongkorn University Bangkok, in: The Salween under threat, Damming the longest free river in Southeast Asia, edited by: Akimoto, Y., 83 pp., http://www.livingriversiam.org/4river-tran/4sw/swd_ book_en.pdf (last access: 21 August 2015), 2004.

Scherer, D., Bookhagen, B., and Strecker, M. R.: Spatially variable response of Himalayan glaciers to climate change affected by debris cover, Nat. Geosci., 4, 156-159, 2011.

Schmidt, C.: As isolation ends, Myanmar faces new ecological risks, Science, 337, 796-797, 2012.

SEAFDEC: Proceedings of the ASEAN-SEAFDEC Conference on Sustainable Fisheries for Food Security Towards 2020 "Fish for the People 2020: Adaptation to a Changing Environment", Vol. II: Thematic Panel Sessions, 13-17 June 2011, Southeast Asian Fisheries Development Center, Bangkok, Thailand, 311 pp., 2012.

Sein, Z. M. M., Ogwang, B. A., Ongoma, V., Ogou, F. K., and Batebana, K.: Inter-annual variability of summer monsoon rainfall over Myanmar in relation to IOD and ENSO, J. Environ. Agr. Sci., 4, 28-36, 2015.

Sen Roy, N. and Kaur, S.: Climatology of monsoon rains of Myanmar (Burma), Int. J. Climatol., 20, 913-928, 2000.

Sen Roy, S. and Sen Roy, N.: Influence of Pacific decadal oscillation and El Niño Southern oscillation on the summer monsoon precipitation in Myanmar, Int. J. Climatol., 31, 14-21, 2011.

Shrestha, S., Thin, N. M. M., and Deb, P.: Assessment of climate change impacts on irrigation water requirement and rice yield 
for Ngamoeyeik Irrigation Project in Myanmar, J. Water Clim. Change, 5, 427-442, doi:10.2166/wcc.2014.114, 2014.

Smakhtin, V. and Anputhas, M.: An assessment of environmental flow requirements of Indian river basins, International Water Management Institute Research Report 107, International Water Management Institute, Colombo, Sri Lanka, 2006.

Smith, B. D., Tun, M. T., Chit, A. M., Win, H., and Moe, T.: Catch composition and conservation management of a human-dolphin cooperative cast-net fishery in the Ayeyarwady River, Myanmar, Biol. Conserv., 142, 1042-1049, 2009.

Thomson Reuters: FACTBOX - Key facts about cyclone Nargis, http://www.reuters.com/article/2009/04/30/idUSSP420097 (last access: 18 August 2015), 2009.

Torrence, C. and Webster, P. J.: Interdecadal changes in the ENSOMonsoon system, J. Climate, 12, 2679-2690, 1999.

Turner, A. G. and Annamalai, H.: Climate change and the Southeast Asian summer monsoon, Nat. Clim. Change, 2, 587-595, 2012.

Union of Myanmar: The Conservation of Water Resources and Rivers Law, http://faolex.fao.org/docs/pdf/mya139027.pdf (last access: 12 November 2015), 2006.

Van der Werf, G. R., Morton, D. C., DeFries, R. S., Olivier, J. G. J., Kasibhatla, P. S., Jackson, R. B., Collatz, G. J., and Randerson, J. T.: $\mathrm{CO}_{2}$ emissions from forest loss, Nat. Geosci., 2, 737-738, 2009.

van Driel, W. F. and Nauta, T. A.: Vulnerability and resilience assessment of the Ayeyarwady Delta in Myanmar, Scoping phase, Bay of Bengal Large Marine Ecosystem (BOBLME) Project, Global Water Partnership (GWP) and Delta Alliance, Delft, Wageningen, the Netherlands, 2013.

Varis, O., Kummu, M., and Salmivaara, A.: Ten major rivers in monsoon Asia-Pacific: An assessment of vulnerability, Appl. Geogr., 32, 441-454, 2012.

Vörösmarty, C. J., McIntyre, P. B., Gessner, M. O., Dudgeon, D., Prusevich, A., Green, P., Glidden, S., Bunn, S. E., Sullivan, C. A., Reidy Liermann, C., and Davies, P. M.: Global threats to human water security and river biodiversity, Nature, 467, 555-561, 2010.
Webb, E. L., Phelps, J., Friess, D. A., Rao, M., and Ziegler, A. D.: Environment-friendly reform in Myanmar, Sci. Lett., 336, 295, 2012.

Webb, E. L., Jachowski, N. R. A., Phelps, J., Friess, D. A., Thand, M. M., and Ziegler, A. D.: Deforestation in the Ayeyarwady Delta and the conservation implications of an internationallyengaged Myanmar, Global Environ. Change, 24, 321-333, 2014.

Webster, P. J.: Myanmar's deadly daffodil. Commentary, Nat. Geosci., 1, 488-490, 2008.

WEPA - Water Environment Partnership in Asia: State of water environment, water-related issues and policies, Myanmar, http://www.wepa-db.net/policies/state/myanmar/myanmar. htm (last access: 25 September 2015), 2014.

Win, Z.: River basins management in Myanmar. Presentation for the International Finance Corporation, World Bank Group, http://www.ifc.org/wps/wcm/connect/ 48d77c00471bb512b04efc57143498e5/2.3.Zaw+Win.pdf? MOD=AJPERES (last access: 13 November 2015), 2014.

Woodroffe, C. D.: Deltaic and estuarine environments and their late Quaternary dynamics on the Sunda and Sahul shelves, J. Asian Earth Sci., 18, 393-413, 2000.

World Bank: Myanmar essential health services access project, Report No. PAD1020, http://www-wds.worldbank. org/external/default/WDSContentServer/WDSP/IB/2014/ 09/25/000470435_20140925101652/Rendered/PDF/ PAD10200PAD0P1010Box385323B00OUO090.pdf (last access: 31 August 2015), 2014.

Xavier, P. K., Marzin, C., and Goswami, B. N.: An objective definition of the Indian summer monsoon season and a new perspective on the ENSO-monsoon relationship, Q. J. Roy. Meteorol. Soc., 133, 749-764, doi:10.1002/qj.45, 2007. 